\title{
Лексическая семантика
}

УДК 801'25

DOI: $10.14529 /$ ling150401

ББК 81 '03

\section{ВАЛЕНТНОСТНОЕ ОКРУЖЕНИЕ ГЛАГОЛА СОЕДИНИТЬ: 1. АГЕНС}

\author{
О.Г. Твердохлеб \\ Оренбургский государственный педагогический университет, г. Оренбург
}

\begin{abstract}
Рассмотрена проблема семантических актантов и семантика глаголов в конструкциях в русском языке. Описываются имена тематического класса лица в позиции субъекта при глаголах соединения. Полученные результаты могут найти применение в практике составления словарей, а также представляют интерес для теории и практики перевода.

Ключевые слова: семантические актанты, лексико-семантическая группа глаголов, субъект, агенс, таксономические классы имен.
\end{abstract}

Лингвистика последних десятилетий достаточно много внимания уделяется вопросу валентностного окружения глагола. Ранее нами уже описывалось валентностное окружение глаголов отделения, разрушения, покрытия [3-5 ]. В этой работе мы также коснемся данной проблемы в связи с исследованием семантических актантов, представленных в субъектной сфере в предложениях с глаголами лексико-семантической группы «соединения» (характеризующиеся помимо общей семантики, еще и общим морфологическим свойством наличием у многих глаголов приставки $c$-/co-, ср.: свинтить/свинчивать, сдвочть/сдваивать, связать/связывать, склеить/склеивать, сколотить/ сколачивать, скрепить/скреплять, слепить/слеплять, слить/сливать, смешать/смешивать, смоmать/сматывать, соединить/соединять, сомкнуть/смыкать, спарить/спаривать, сплотить/ сплачивать, спрессовать/спрессовывать, срастить/сращивать, сцепить/сиеплять и т. п.).

Глаголы лексико-семантической группы «соединения» обладают агентивной валентностью, или АГЕНСОМ ( - по Е.В. Падучевой, или sub (субъект) - по Ю.Д. Апресяну), обычно понимаемые как обладающие «потенцией», «собственной внутренней энергией» [6 ] и являющиеся причиной обозначаемого глаголом действия. Приведем примеры: Хирург блестяще соединил не только кровеносные сосуды, но и нервные окончания, и сухожилия, и мышиы, и кость. (В.Д. Захарченко. Разг. с электр. мозгом); Влюбленные ...наконеи, соединяют свои жизни. (С. Соловейчук. Учение с увлеч.); На животике мальчик связал эти полоcbl кушаком... (М.М. Пришвин. Клад.солнца); ...Все это мы связали в узел... (Бруштейн. Дорога...); Мне купили столярные инструменты, и иеельмм часами я пилил, строгал, сколачивал. (А.С. Яковлев. Воспитатели); Этой ручкой... союзники скрепляли акт о капитулящчи гитлеровской Германии... (Соверш. секретно, 05.05.03);
«Узлом жизни» скрепили жрецы врата, ведущуие $\kappa$ саркофагу фараона Тутанхамона. (В. Бурлак. Хранит. др. тайн); Люди ...затем сиивали эти икуры сухожилиями. (Антропология. 110). Нами было исследовано более 3000 конструкций, включающих глаголы этой лексико-семантической группы. Не претендуя на полноту выборки, мы, однако, на основании рассмотренного материала можем сделать некоторые замечания.

Семантической роли АГЕНС могут соответствовать разные таксономические классы (тематические классы, «в логике это предметные переменных или категориальные предпосылки предмета - такие как лицо, природная сила и под.» $[2$, c. 53]. АГЕНСОМ ситуации, описываемой в предложении глаголами исследуемой группы, могут быть представлены имена Т-класса

1) лица (человек, люди), в том числе этнонимы; имена родства и сверхъестественные существа (русалка, инопланетянин, ср., напр. :

- имена лиц: Князья смоленский, рязанский, муромский, полочкий вторично соединили свои дружины с его многочисленными полками. (Н.М. Карамзин. Ист. гос. Рос. Т. 3);

- этнонимы: Скифы соединили все свои три армии (Б.А. Рыбаков. Геродотова Скифия); Во время нашего отсутствия японцы соединили мой коридор с коридором господина мура (В.М. Головин. Зап. флота капит...);

- сверхъестественные существа: И что таков закон Бога, и что то, что Бог соединил, человек не должен разделять. (Л.Н. Толстой. Путь жизни); То-то господь-батюшка соединил бы с нашей Лизонькой их графское сиятельство. (А.И. Эртель, Гарденины); ...фея их соединяет (А. Бенуа. Жизнь художн. ...); ...имаман ...ищет беглую душу больного, хватает ее и снова соединяет с телом... (М. Элиаде. Шаманизм).

2) животные: ...когда пчелы соединяют две половины сотов... (Р. Шовен. От пчелы до гориллы); 
3) растения: Прорастая, эти растения своими корнями скрепляют воздушные муравейники... (Г.А. Денисова. Удив. мир. растений, 48).

Важным при этом оказывает то, что перечисленные таксономические классы имен (лица, животные и растения) обнаруживают между собой гипонимичные (родо-видовые) отношения, являясь между собой согипонимами по отношению к гиперониму «живые организмы».

Имена описанной группы представлены в нашей картотеке в субъектной позиции: а) при глаголе в активной форме (абсолютное большинство случаев): именем существительным в именительном падеже (чаще): Люседимитрий соединил полки свои и напал на Куракина. (Н.М. Карамзин. Ист. гос. Рос., Т. 12); местоимением в именительном падеже (реже): Но иногда я соединял его разные фразы вместе... (А. Солженицын. Арх. ГУЛАГ); ...каждый ...соединяет три перста правой руки (Макарий. Ист. рус. церкви); Сцепщчики - это люди, которые соединяют тормозные иланги.. (О. Зайончковский. Счастье возможно); субстантивированным именем прилагательным в именительном падеже (единичный пример): Другие ...скрепляют строки новыми рифмами... (В.В. Маяковский); именем числительным в именительном падеже (единичный пример): ...эmи трое взяли по стакану и соединили их для чоканья (М. Алексеев. Драчуны), и б) при глаголе в пассивной форме (единичный пример) именем существительным в творительном падеже (чаще): ...акт, который скрепляется канцлером юстицзии...(М.М. Сперанский. Введ. к улож. гос. зак.).

АГЕНСОМ ситуации, описываемой в предложении глаголами исследуемой группы, могут быть представлены имена Т-класса животные, названные при глаголе в активной форма в субъектной позиции: именем существительным в именительном падеже, ср.: Onытные жсивотные, получающие две палки в отсутствие пищи, как правило, соединяют их вместе не более чем за час. (Р. Корсини, А. Ауэрбах. Псих. энц.); Забравиись на высокий сук, белка плотно соединяет вместе лапь... (В. Песков, Б. Стрельников. Земля за океаном); местоимением в именительном падеже, ср.: ...иимпанзе успешно удлиняли короткие палки, то в других они соединяли их под углом... (3.А. Зорина, А.А. Смирнова. О чем расск. «говорящ. обезьяны»); или числительным в именительном падеже, ср.: Иногда голубка не хочет иеловаться, и голубь долго старается разжать ей стиснутый носик; обыкновенно же оба соединяют свои разинутые носы... (С.Т. Аксаков. Зап. ружей. охотн.).

АГЕНСОМ ситуации, описываемой в предложении глаголами исследуемой группы, могут быть представлены и имена Т-класса растения. В нашей картотеке примеры описываемой группы единичны и представлены лишь конструкциями с глаголом соединить и скрепить в активной форме: именем существительным в именительном падеже, ср. Прорастая, эти растения свочми корнями скрепляют воздушные муравейники... (Г.А. Дени- сова. Удив. мир. растений, 48); или местоимением в именительном падеже, ср.: Наконец, появляются ...тальник, ива, даже ольха и береза: они окончательно скрепляют почву свочми корнями... (С.Т. Аксаков. Зап. руж. охот.).

Единичен пример с именем Т-класса растения, названным в субъектной позиции при глаголе соединить в активной форме: Иггдрасиль считается вечнозеленым древом жизни и судьбы. Он соединяет различные миры (Е. Доброва. Поп. ист. мифол.), но в этом примере имя Т-класса растения контаминируется с именем Т-класса лица сверхъестественные существа.

АГЕНС ситуации, описываемой в предложении глаголами соединения, на наш взгляд, может быть представлен не только лексемами указанных Т-классов, но и лексемами мереологического поля (- в терминах Национального корпуса русского языка) «множества и совокупности объектов». Мы называем их субактанты. В субъектной сфере в качестве СУБАГЕНСА при глаголах соединить могут быть репрезентированы лексемы мереологического поля, называющие:

- множества и совокупности лиц(типа толпа, группа, коллектив и т.п.): Войско монгольское стрелами и ядрами сшивало людей друг с другом. («Наука и Жизнь», 97-3, 82); Группа ученых ...соединила в единую систему первые четьре компьютера крупнейших исследовательских учреждений США (Ю. Рылёв. ХХ век: энц. изобретен.); Племя персов ...вдохнуло новые силь в иранские племена и соединило их в огромную монархию (Н.Я. Данилевский. Россия и Европа);

- множества и совокупности животных (типа табун, стадо, рой): ...утром, когда их (жаворонков - О.Т.) стая... соединяла свои голоса в тот мощчный звучащий собор... (В. Хлебников. Скуфья скифа); Твой брак был заключен на лампочке, И мух-гостей орава цуелая Соединила ваши лапочки. (Н. Богословский. Замет. на полях шляпы);

- лексемы множества и совокупности растений (типа набор, букет, копна, скирдаи пр.) в субъектной позиции нами не обнаружены.

Таким образом, традиционно выделяемым актантам соответствуют разные таксономические классы имен. Так, АГЕНСУ глаголов лексикосемантической группы соединение соответствуют разные (но обнаруживающие между собой согипонимичные отношения), таксономические классы: а) лица и сверхъестественные существа; б) животные и в) растения.

АГЕНС ситуации, описываемой в предложении глаголами «соединения», может быть представлен также субактантами (репрезентированными лексемами поля «множества и совокупности объектов»).

\section{Лuтература}

1. Апресян, Ю.Д. Избранные труды: В $2 \mathrm{~m}$. T. 1: Лексическая семантика: Синонимические средства языка. Т. 2: Интегральное описание языка и системная лексикография / Ю.Д. Апресян. M., 1995. 
2. Падучева, Е.В. Динамические модели в семантике лексики / Е.В. Падучева. - М.: Языки славянской культуры, 2004. - 608 c.

3. Твердохлеб, О.Г. Валентностное окружение глаголов лексико-семантической группь «отделение» // Вестник Оренбургского педагогического университета. "Естественные и гуманитарныле науки». - 2007. - № 2 (48). - C. 56-62.

4. Твердохлеб, О.Г. Валентностное окружение глаголов лексико-семантической группь «покрытие» / О.Г. Твердохлеб // Русский язык как средство межскультурной коммуникачии и консолидации современного общества: матер. Межд. науч.-практ. конф. - Оренбург: Изд-во ОГПУ, 2007. - T. 1. - C. 127-131.

5. Твердохлеб, О.Г. Валентностное окружение глаголов лексико-семантической группь "разрушение» / О.Г. Твердохлеб // Русский язык: исторические судьбы и современность: ІІІ Межд. конгресс исследователей русского языка. Труды и матер. - М.: МАКС Пресс, 2007. C. $152-153$.

Твердохлеб Ольга Геннадьевна, кандидат филологических наук, доцент кафедры языкознания и методики преподавания русского языка, Оренбургский государственный педагогический университет (Оренбург),ogtwrd@gmail.com

Поступила в редакцию 2 марта 2015 2.

DOI: 10.14529/ling150401

\section{VALENCY OF THE VERB "TO CONNECT": 1. THE AGENT}

O.G.Tverdokhleb,ogtwrd@gmail.com

Orenburg State Pedagogical University, Orenburg, Russian Federation

This author considers the problem of semantic role and semantics of verbs used in constructions in the Russian language. The article deals with nouns of the thematic class of the person in the position of the subject to the verb with the meaning of connection. The results of the present research can be used in lexicography as well as in theory and practice of translation.

Keywords: semantic role, lexico-semantic group of verbs, subject, agent, taxonomic classes of nouns.

\section{References}

1. Apresyan Y.D. Izbrannyie trudyi: V 2 t. T. 1: Leksicheskaya semantika: Sinonimicheskie sredstva yazyika. T. 2: Integralnoe opisanie yazyika I sistemnaya leksikografiya. 「Selected Works: In 2 vv. vol. 1: Lexical Semantics: Synonymous Means of Language. V. 2: Integrated Description of Language and System Lexicography]. Moscow, 1995.

2. Paducheva E.V. Dinamicheskie modeli v semantike leksiki. [Dynamic Model of Semantics Vocabulary]. Moscow, Languages of Slavonic culture, 2004. 608 p.

3. Tverdokhleb O.G. Valentnostnoe okruzhenie glagolov leksiko-semanticheskoy gruppy i «otdelenie». [Valentone Environment Verbs Lexico-Semantic Group of Department]. Vestnik Orenburgskogo pedagogicheskogo universiteta. «Estestvennyie i gumanitarnyie nauki». 「The Bulletin of the Orenburg State Pedagogical University. Seriya "Natural and Humanitarian Sciences"7. Orenburg. 2007. No. 2 (48). P. 56-62.

4. Tverdokhleb O.G. Valentnostnoe okruzhenie glagolov leksiko-semanticheskoy gruppy i «pokryitie». [Valentone Environment Verbs Lexical-Semantic Group "Coverage" 7 . Russkiy yazyk kak sredstvo mezhkul'turnoy kommunikatsii i konsolidatsii sovremennogo obshchestva. Mater. Mezhd. nauch.-prakt. konf. 「Russian Language as a Means of Intercultural Communication and Consolidation of the Modern Society. Materials Int. SciencePractical Conference]. Orenburg: Publishing house of the OGPU, 2007. Vol. 1. P. 127-131.

5. Tverdokhleb O.G. Valentnostnoe okruzhenie glagolov leksiko-semanticheskoy gruppy «razrushenie». 「Valentone Environment Verbs Lexical-Semantic Group "Destruction" 7 . Russkiy yazyk: istoricheskie sud'by i sovremennost': III Mezhd. kongress issledovateley russkogo yazyka. Trudy i mater. [Russian Language: Historical Destiny and Present State: III Int. the Congress of Russian Language Researchers. Labor and Materials]. Moscow, MAKS Press, 2007. P. 152-153.

Olga G. Tverdokhleb, Candidate of philological Sciences, associate Professor of linguistics and methods of teaching the Russian language, Orenburg state pedagogical University (Orenburg), ogtwrd@gmail.com

Received 2 March 2015

\section{ОБРАЗЕЦ ЦИТИРОВАНИЯ}

Твердохлеб, О.Г. Валентностное окружение глагола соединить: 1. Агенс / О.Г. Твердохлеб // Вестник ЮУрГУ. Серия «Лингвистика». - 2015. - Т. 12, № 4. C. 5-7. DOI: $10.14529 /$ ling 150401

\section{FOR CITATION}

Tverdokhleb O.G. Valency of the Verb "to Connect": 1. The Agent. Bulletin of the South Ural State University. Ser. Linguistics. 2015, vol. 12, no. 4, pp. 5-7. (in Russ.). DOI: 10.14529/ling150401 